\title{
Oriental Cults and Curse Tablets in Europe
}

\author{
Michaela Kellová \\ (Charles University, Prague)
}

\begin{abstract}
In my paper, I would like to explain that there is an interesting connection between spreading oriental cults and curse tablets. I will show the spreading of these cults through Europe, especially cults of Isis, Seth, Magna Mater or Attis. Concretely I will focus on one of the most important sites dedicated to oriental gods, concerning the defixiones, which is the dual shrine of Magna Mater and Isis in Mainz, ancient Mogontiacum. This site is extraordinary in several ways. However, I would like to primarily focus on the deposition of the thirty-four tablets which were found there. They are interesting according to the fact that their location differs from the tablets found in the other temples and sites, as I will present. Other sites connected with oriental cults mentioned above will be examined in the similar way (tablets from Rome or Athens). The comparison between Greek and Latin tablets will be part of the presentation as well.
\end{abstract}

\section{Keywords}

Oriental cults; curse tablets; Mainz; archaeological context 


\section{Introduction}

Curse tablets are artefacts of a magical nature. They have their epigraphic, archaeological and partially religious value and they are an insight to the thinking of average people. These tablets are mostly made of lead, but also other materials are possible (e. g.: wax.). Curses are written on thin sheets in various languages, but mainly in Latin or Greek. Mostly they are aimed against competitors of the authors- for love, trial or sport, or a thief who robbed the author. Usually, they are placed in graves, water sources or sacred places.

Curse tablets are often connected with gods; by place of deposition, the list of deities on tablets themselves, etc. The connection to chthonic deities is very well known, e.g.: Roman tablets invoking Proserpina and Pluto from the first half of the first century $\mathrm{BC}^{1}$. In the same way, as these gods were treated the oriental deities. Most of them are often linked with mysteries.

This study is aimed to correlate the archaeological deposition of the tablets which are somehow connected to the oriental gods with their textual value. The paper concerns primarily Latin tablets.

Firstly, it should be worthy to mention that from plenty of oriental gods and goddesses not all are mentioned on defixiones. For this study three of them are crucial: Magna Mater, Isis and Seth.

"It is typical of the gods of the oriental cults that they have some experience of human existence characterised by direct contact with death." 2 This is true for all mentioned gods and it is one reason to connect them with curse tablets

\section{Magna Mater}

According to Lynn Roller, the human devotion to Magna Mater began in the early first millennium BC. ${ }^{3}$ The cult originates in central Anatolia, especially in Phrygia. The goddess was firstly mentioned in the seventh century BC inscriptions ${ }^{4}$ while calling her just Matar (mother). "While this word usually appears alone, in two cases there is a qualifying adjective, kubileya, a word that appears to have meant "of the mountain" in the Phrygian language." Thus we can consider her to be "mother Nature" for the Phrygians. However, in the second century $\mathrm{AD}$, the goddess was usually called Mother Goddess. ${ }^{6}$ The Phrygian mother goddess was depicted differently than Greek. The only attribute which is similar is a lion. Greeks made this deity more mystic by arrogating to her a tympa-

1 The tablets were probably found under Porta Salaria in Rome. Kropp (2008: dfx. 1.4.4/8-12).

$2 \quad \operatorname{Alvar}(2008:$ p. 33).

3 Roller (1999: p. 1).

4 Roller (1999: p. 66) mentioned ten Paleo-Phrygian inscriptions.

$5 \quad$ Roller (1999: p. 2).

$6 \quad$ Roller (1999: p. 2). 
num. ${ }^{7}$ Meter is, as Demeter, linked with the Greek god Hermes. There are several votive reliefs of Meter with him next to her. ${ }^{8}$ One of curse tablets (Kropp 2008: dfx. 5.1.5/1) from Mogontiacum disposed in water source names Hermes. ${ }^{9}$ This god also conducted initiates into the mysteries. ${ }^{10}$

For the Greek mainland, the most important site was Metroon in Athens. The Roman Empire introduced the cult of Magna Mater into Rome in 204 BC. Here, on the Palatine, the simulacre of her was placed in the temple of Victoria. She should have protected Rome against Hannibal during the Second Punic War. ${ }^{11}$ She was a protectress of Rome until the end of the fourth century $\mathrm{AD},{ }^{12}$ after that she was treated in sharp contrast to her invitation. She was even proscribed. ${ }^{13}$

Two sites concerning curse tablets naming Magna Mater are to be mentioned in the paper: Mogontiacum (Germany) and Kempraten (Switzerland). There are at least two other sites connected to the cult of Cybele, Gross-Gerau (Germany) and Alcacér do Sal (Portugal), where Attis, the lover of Magna Mater, is invoked.

\section{Mogontiacum}

The most important site of worship of Magna Mater connected to cursing was Mogontiacum, nowadays Mainz. The temple dedicated to Magna Mater and Isis was excavated here in 1999. ${ }^{14}$ It was built during (or slightly after) reign of Vespasianus (AD 69-79). A great number of curses (thirty-four) and magical figurines were found in the sanctuary. Five of these tablets are devoted to Magna Mater and one to Attis (her lover). ${ }^{15}$ The date of founding the temple between AD 71 and 80 was established according to the dedicatory inscription. ${ }^{16}$ "The cult of Magna Mater, though viewed as an Oriental cult initially, may have appealed to Romans because she originated from Anatolia," ${ }^{17}$ as well as Aeneas, the founder of the Roman state. According to Virgil, Magna Mater is the protector of Aeneas and his alma mater. ${ }^{18}$

\footnotetext{
$7 \quad$ Roller (1999: p. 139).

8 Roller (1999: p. 176).

9 Kropp (2008).

10 Roller (1999: p. 202).

11 Roller (1999: p. 264).

12 Tortchinov (1998: p. 150).

13 Alvar (2008: p. 243).

14 Chalupa (2011: p. 237).

15 Chalupa (2011: p. 237).

16 Gordon (2011: p. 6).

17 Eiland (2004: p. 25).

18 Roller (1999: p. 7).
} 
Tablets were explored and published by J. Blänsdorf in Die Defixionum tabellae des Mainzer Isis- und Mater Magna-Heiligtums (DTM). ${ }^{19}$ Most of the tablets are prayers for justice "and most of them, were intended to be burned in a firepit." ${ }^{20}$ It was suggested by B. $\mathrm{Zach}^{21}$ that these firepits were made to place offerings to patron deities. ${ }^{22}$ There are traces of melting on some of the defixiones. ${ }^{23}$

Most of the tablets were found in the inner courtyard (twenty-seven), which was the main area to place the burned offerings ${ }^{24}$. In this courtyard, a masonry shaft consisting subsequently of other three masonry burnt-offering places, as it is visible on the plan (fig. 1), was excavated. Shaft A is the oldest part, place B was built later with one wall common. As it is shown the place $\mathrm{C}$ is overlaid by burnt-offering place $\mathrm{D}$. The coins from place D are assigned to Domitian and Trajan. The most recent coin from place $\mathrm{C}$

(13)

(30)

(26)

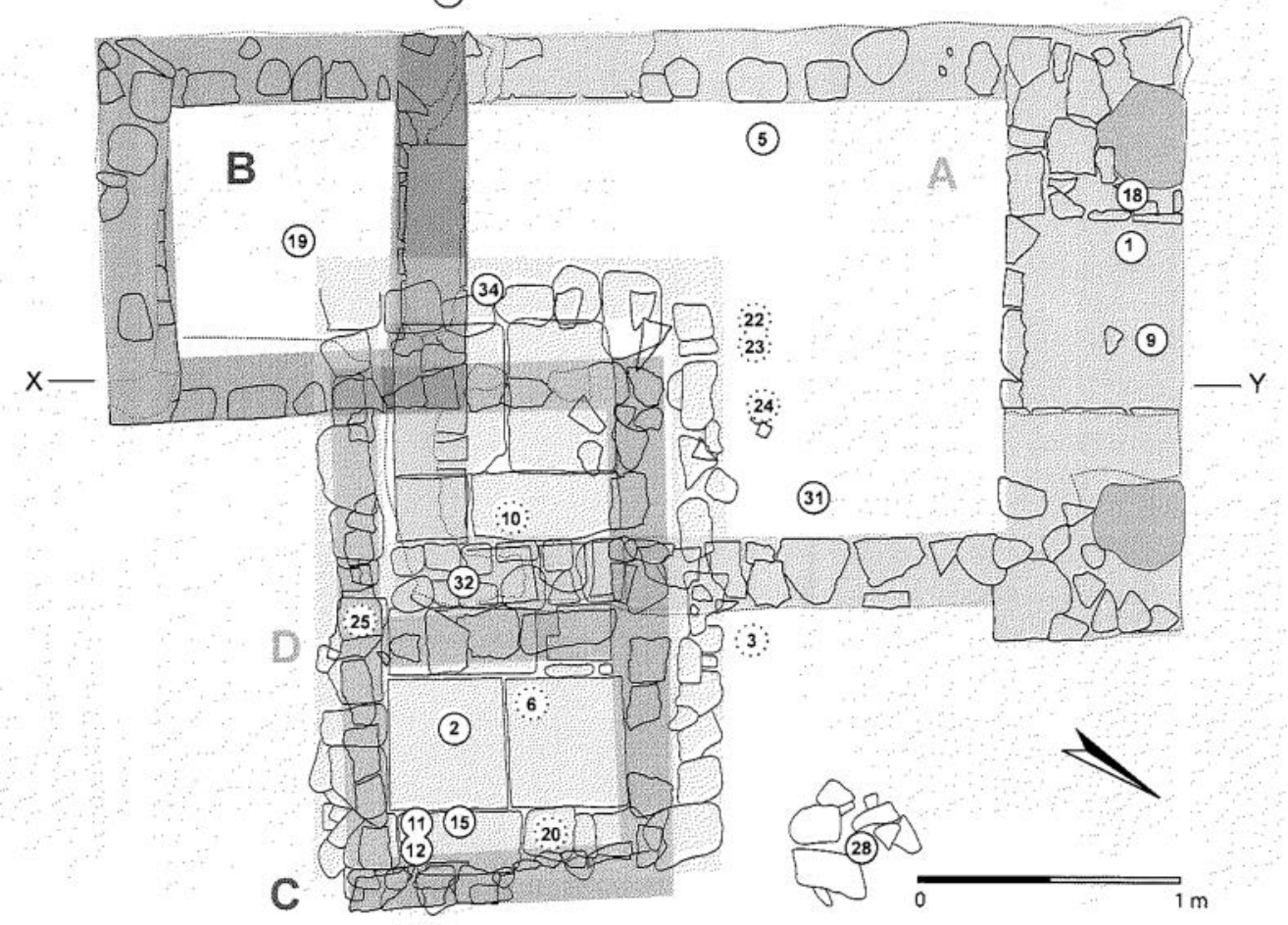

Fig. 1

19 Blänsdorf (2012).

20 Veale (2017: p. 279).

21 Zach (2002: pp. 101-103).

22 Veale (2017: p. 281).

23 Veale (2017: p. 279).

24 Witteyer (2004: p. 25) 
was minted by Titus..$^{25}$ Well the tablets from place $\mathrm{C}$ are older than from place $\mathrm{D}$ which should probably be dated after AD 81 to the beginning of the second century AD.

DTM 1 was discovered along to DTM 9 in a firepit in the inner courtyard (A). This part of the sanctuary is the oldest. Also, oil lamps and some pottery were found in this firepit which was probably meant to be a place to make offerings to patron deities. ${ }^{26}$

Reading: A: Mater Magna, te rogo p(e)r (t)ua sacra et numen tuum: Gemella fiblas meas, qualis sustulit, sic et illam REQUIs (rogo?) adsecet, ut nusquam sana si(t). Quomodo galli se secarunt, sic ea (m?) velis nec se secet sic, uti planctum ha(be)at, quomodo et sacrorum deposierunt in sancto, sic et tuam vitam, valetudinem, Gemella. Neque hosti(i)s neque auro neque argento redimere possis a Matre deum, nisi ut exitum tuum populus spectet. Verecundam et Paternam: sic illam tibi commendo, Mater deum magna, rem illorum in AECRUMO DEO VIS quale rogo co $(n)$ sument(u)r, quomodo et res meas viresque fraudarunt, nec se possint redimere nec hosteis lanatis

$B:$ nec plum $\{i\}$ bis nec auro nec argento redimere a numine tuo, nisi ut illas vorent canes, vermes adque alia portenta, exitum quarum populus spectet tamquam quae $\{C\}$ FORRO/MO L(.) auderes comme (ndo) duas ... further very corrupted text TAMAQVANIVSCAVERSSO scriptis istas AE RISS. ADRICIS . S. LON a . illas, si illas cistas caecas, aureas, FECRA E[-]I[-]LO[-] ASO OV[-]EIS mancas A

Translation: Magna Mater, I ask you, by your sacred rites and divine spirit: Gemella, the one who took my brooches, seek her out and cut her, so that she is never well. In the manner that the galli cut themselves, so too let her [not] cut herself, but let her wail in this way. And just as they make a deposit of their sacred things in the sacred treasury, thus should your life and health [be deposited], Gemella. Neither with animal sacrifices, nor with gold, nor with silver, will you be able to redeem yourself from the Holy Mother, unless it so happens that the people watch you die. Verecunda and Paterna: I thus entrust their situation to you, Sacred Great Mother ... I ask that they are destroyed in the manner that they defrauded the affairs of me and my husband. Let them not be able to redeem themselves from your power, neither with sacrifices of sheep // nor with lead tablets, nor with gold, nor silver, unless dogs and worms and other monsters devour them. Let the people see their death, just as . . . two women. . . just like this, let justice turn back these women, like these writings . . if those hidden, golden, and sacred baskets . . . ${ }^{27}$

The cursed person's name is Gemella. The galli ritual is mentioned: “...it appears that the curse practitioner hopes that Gemella does not harm herself with cutting like the galli but does hope that she experiences their anguish. Thus, the hope is likely that Gemella goes mad or experience mental remorse." ${ }^{28}$ Such mental remorse could be defined by Hippocrates who claims that Magna Mater was responsible for the 'Sacred Disease', which means epilepsy. ${ }^{29}$

25 Blänsdorf (2012: Abb. 3).

26 Veale (2017: pp. 281-282).

27 Translation by Veale (2017: pp. 281-282)

28 Veale (2017: p. 282).

29 Roller (1999: p.156). 
DTM 2 was found in the burnt-offering place C. In the same area, there were seven more tablets discovered. ${ }^{30}$ It was placed in a firepit as well as DTM 11/12 and DTM 15. ${ }^{31}$

Reading: Quisquis dolum malum adm(isit de), hac pecun(i)a ... ille melior et nos det(eri) ores sumus ... Mater deum, tu persequeris per terras, per (maria, per locos) ar(i)dos et umidos, per benedictum tuum et o(mne ... qui de hac) pecunia dolum malum adhibet, ut tu perse(quaris illum ... Quomodo) galli se secant et praecidunt vir(i)lia sua, sic il(le)... R $S$ Q intercidat MELORE pec(tus?)... BISIDIS (ne)que se admisisse nec ... hostiis si(n)atis nequis $t(. .$.$) neque SUT(.)$ TIS neque auro neque argento neque ille solvi, (re)fici, redimi posit. Quomodo galli, bellonari, magal( $i$ ) sibi sanguin( (em) ferventem fundunt, frigid(us) ad ter ram venit, sic et (...)CIA copia, cogitatum, mentes. (Quem)admodum de eis gallo(r)u(m, ma)galorum, bellon(a-riorum sanguinem/ ritus?) spectat, qui de ea pecunia dolum malum (admisit, sic illius) exitum spectent, et a (d qu)em modum sal in (aqua liques)cet, sic et illi membra m(ed)ullae extabescant. Cr(a)s (veniat) et dicat se admisisse nef(a)s. D(e)mando tibi rel(igione), ut me votis condamnes et ut laetus libens ea tibi referam, si de eo exitum malum feceris.

Translation: Whoever did this crime and stole this money . . . that man is richer and we are poorer. Sacred Mother, may you pursue him across the earth, through the sea, through the wet and dry places, by your righteous one [Attis] and all . . . Let this money bring harm and misfortune because you pursue him ... In the way that the galli cut themselves and cut off their testicles, thus let that man . . . cut . . . his chest [?]. Do not allow him to redeem himself . . . neither with sacrifices, nor with . . . nor with gold or silver, nor should that man be able to be saved or restored or redeemed. In the way that the galli, the Bellonari, and the Magali shed their boiling-hot blood, let him come cold to the ground, also [let him shed] his faculties, his thinking, and his intentions. He will see the extent of the [powers] of the galli, Magali, and Bellonari. The one who did the crime of [taking] this money, let them see him die, and for the same reason that salt dissolves in water, similarly let that man's limbs and marrow disappear. Let him be tortured and let him say that he admits his crimes. I entrust [him] to you with a solemn oath, so that you may find him guilty by my prayers. If you cause a bad death for this reason, I will return these things to you gladly and freely. ${ }^{32}$

DTM 3 was located alone just outside the wall of the inner courtyard. ${ }^{33}$

Reading: A: Rogo te, domina Mater Magna, ut me vindices de bonis Flori coniugis mei, qui me fraudavit Ulattius Severus. Quemadmod(um) hoc ego averse scribo, sic illi

B: omnia, quidquid agit, quidquid aginat, omnia illi aversa fiant, ut sal et aqua illi eveniat. Quidquid mi abstulit de bonis Flori coniugis mei, rogo te domina Mater Magna, ut tu de eo me vindices.

Translation: I ask you, Mistress Magna Mater, that you avenge me concerning the goods of my spouse Florus. Ulattius Severus is the one who cheated me, and in the manner that I write this backwards, thus should all that man's affairs, whatever he does, whatever he may pursue, let all things of that man be reversed, let it come to that man like

30 According to Blänsdorf (2012: Abb. 4).

31 According to Blänsdorf (2012: Abb. 6).

32 Translation by Veale (2017: p. 283).

33 Veale (2017: p. 284). 
salt and water. Whatever he took from me concerning the goods of Florus my spouse, I ask you Mistress Magna Mater, that you avenge me for it. ${ }^{34}$

DTM 4 wasn't found in the main part of the temple, but in newer area. ${ }^{35}$

Reading: A: Tiberius Claudius Adiutor in megaro eum rogo te, Mat(e)r Magna, megaro tuo recipias. Et Attis domine, te precor, ut hu(n)c (h)ostiam acceptum (h)abiatis et quit aget, aginat sal et aqua illi fiat. Ita tu facias dom(i)na it, quid cor eoconora c(a)edat.(?) B: Devotum defictum illum menbra, medullas \{AA\}. Nullum aliud sit, Attis, Mater Magn(a).

Translation: Tiberius Claudius Adiutor: I ask in your temple, Magna Mater, that you receive him in your temple. And Lord Attis, I beseech you that this man is accepted like a sacrifice, and whatever thing he does or make, let it be like salt and water for that man. May you make it so, Mistress, let this happen, let him cut his heart and liver. // Since that man and his limbs and marrow have been bound and consecrated [to you] . . . let there be nothing else, O Attis and Magna Mater. ${ }^{36}$

DTM 6 was found in a place D which overlay place C. ${ }^{37}$

Reading: Quintum in hac tabula depon(o) aversum se suisque rationibus vitaeque male consumantem. Ita uti galli, Bellonarive absciderunt, concideruntve se, sic illi abscissa sit fides, fama, faculit(a)s. Nec illi in numero hominum sunt, neque ille sit. Q(u)omodi et ille mihi fraudem fecit, sic illi, sancta Mater Magn(a), et relegis(ti) cuncta. Ita uti arbor siccabit se in sancto, sic et illi siccet fama, fides, fortuna, faculitas. Tibi commendo, Attihi d(o)mine, ut me vindices ab eo, ut intra annum vertente ( $m$...) exitum illius vilem malum.

B: (rotated $90^{\circ}$ in the left): ponit nom(en) huius maritabus I si agatur ulla res utilis, sic ille nobis utilis sit suo corpore. Sacrari horr(e)bis.

Translation: I place [with you] Quintus, who has turned away from himself and his life concerns and has acted badly. Just as the galli and Bellonari cut themselves and fall to the earth, thus let his credibility, his reputation, and his abilities be cut off. Since those men are not reckoned in the number of men, do not let that man [be reckoned in the number of men]. Just like that man deceived me, thus holy Magna Mater, may you take away all his possessions. Like the tree that dries up in your sanctuary, thus let the reputation, credibility, and ability of that man dry up. I entrust [him] to you lord Attis, so that you will avenge me for this, and that, within the turning of the year, his death will be bad and vile. // He places the name with the spouses . . . If anything, useful will be done, so then that man will be useful to us in his body. You will fear to be

consecrated [to the gods]. ${ }^{38}$

Gordon supposes that: “... the ritual involved sacrificing an animal or other offering and melting the inscribed lead tablet in the flames so that it passed 'into' the other world." 39

34 Translation by Veale (2017: p. 284).

35 Veale (2017: p. 288).

36 Translation by Veale (2017: pp. 287-288).

37 According to Bländorf (2012: Abb. 3).

38 Translation by Veale (2017: p. 285).

39 Gordon (2011: p. 6). 
According to Veale: "The language on the tablets strengthens the connection between the curse tablets and votive offerings. Seven tablets (DTM 1, 2, 4, 6, 8, 11, 28) use language that can be considered votary. Four employ Latin word for a vow or a cognate (votum, devoveo, religione). Five (DTM 1, 2, 4, 6, 8) mention offering the curse tablet or the tablet's victim as if it were a sacrifice to the gods." ${ }^{40}$ The offering of the cursed person or the stolen object can be observed on some curse tablets from Roman Britain, e.g. the curse tablet from Lydney Park, as it is used for the prayers for justice.

\section{Kempraten}

The gallo-roman temple precinct was discovered in $2009 .{ }^{41}$ It is a complex of two temples, two chapels and one fire altar. ${ }^{42}$ There are two phases of usage: the first phase lasted during the second century $\mathrm{AD}$, the second phase starts in the end of the second century and lasted to the fourth century AD. ${ }^{43}$ Five curse tablets were found in the precinct. Two tablets were deciphered, one tablet is still unrolled, and two tablets are very fragmentary. ${ }^{44}$

DTK 1 "was probably buried to the east of the larger temple in the former court of the temple district, as can be seen from the translation of the text. The younger phase of the temple district dates from the current status of the evaluation of the findings in the end of the second and third centuries". The tablet is probably dated to this period..$^{45}$ The context was not the firepit like in Mainz. However, it still has traces of heating- the colour of the lead changed to blue. ${ }^{46}$ The tablet was scribed on both sides.

Reading: RECTO: [Mag]na Mater |[....]na rogat $S+q u a c a \mid[. .$.$] am ex tuis ancillis: |quisquis$ horreum |Catullinae effregit |Lindomagi siue f[en]es-|tram siue culcitr[a]m |Asiatici et qui lucer[n]am |eius sustulit et qui |conscius est et qui |dolum malum

VERSO: Facit, sic iace[at] |+++ micto que[m]-|admodum haec |epistula iacitu-|ra est.

Translation: Magna Mater! [...]a asks S + quaca [...] from your helpers: Whoever broke open the barn of Catullina in Lindomagus, or the window or the cushion of the Asiaticus, and who stole his lamp and who is aware of that fraud. By doing so, may he lie in dirt just as this letter will lie (in dirt). ${ }^{47}$

It is a prayer for justice while invoking Magna Mater to be the one who should punish an unnamed/unknown person(s). As It has been already mentioned, also tablets from Mainz are meant to find justice.

40 Veale (2017: p. 302).

41 Koch (2011: p. 113).

42 Ackermann (2013: p. 254).

43 Koch (2014).

44 Koch (2011: p. 113).

45 Koch (2011: p. 113).

46 Koch (2011: p. 113).

47 Transliteration and translation to German in Koch (2011: p. 118). English, translation by the author. 
The shape of the tablet resembled tabula ansata. ${ }^{48}$ However, it is incomplete. The word Mater has been centred on the first line. Because of this fact, it is supposed that an address of the goddess should be a title of the tablet Although, only two remaining letters, of the very first word, are visible, it is very probable that it means magna. ${ }^{49}$

\section{Isis}

"The cult of Isis has been associated with Egypt, where its origins may be ascribed to the fourth millennium BC". The spread of worship the Egyptian Mater deum relates to the raising power of the Ptolemaic dynasty. ${ }^{50}$ The "Isiac cults" were specifically developed during Hellenistic and Roman eras. ${ }^{51}$ It reached Italy in the second and Rome in the first century BC. The goddess got her temple in Rome on Capitol in 105 BC. ${ }^{52}$ However, the cult was not popular until Caligula (AD 37-41). Isis was often syncretised with other mother goddesses. ${ }^{53}$

The goddess is pictured as a universal and global deity by the hymn from the Vienna papyrus $^{54}$. „Isis rules over the south, the north, the east and the west. In between the various peoples, in the right column and on the left, the respective foreign, non-Egyptian names are attributed. Thus, Isis is responsible for the Ionians, i.e. in Egyptian terminology for the Greeks, and there she is called Demeter. Among the Medes her name is Anāhìta, among the Assyrians Nanaia and so on. The line concerning the Persians poses a particular problem, where our goddess, presumably Isis, corresponds to a certain Athyna ('thynз) or Athynen ('thynn) or Lathyna (L'thyns) or Lathynen (L'thynn) as the chief goddess." 55

„In Pharaonic Egypt, Isis was considered to dispose of great magical power." 56 In Greek Magical Papyri, several spells are invoking Isis. Just one and "no other magical text in the Graeco-Egyptian tradition found outside Egypt (which essentially means Rome, Athens, Carthage and Hadrumetum, with a scattering elsewhere) so much as mentions Isis, even in the context of erotic praxeis. If we extend the search to include Isiac deities, with the very important exception of the Porta S. Sebastiano texts from Rome, which date to the late fourth century AD, Osiris is invoked in just two texts, Sarapis in one only." ${ }^{57}$ However, there are two curse texts from European provinces from two sites: Bolonia (Spain) and one of the tablets from Trier (Germany).

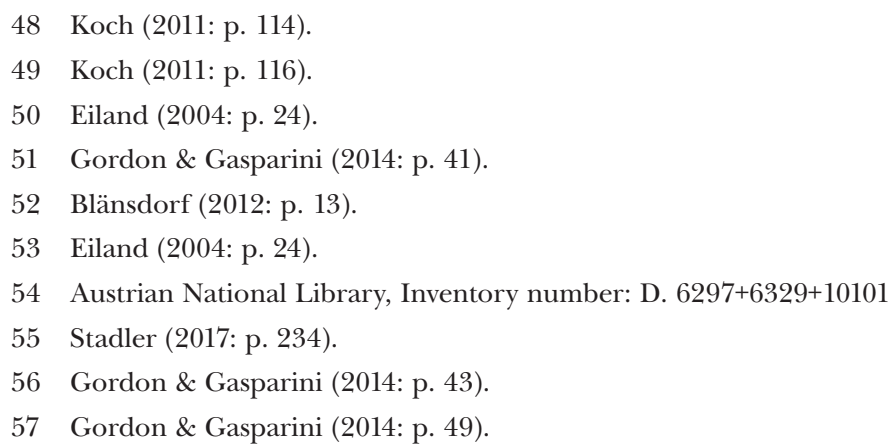




\section{Belo (Bolonia)}

The site is connected to Isis, as the sanctuary is devoted to her. The tablet was found in a well situated in the sanctuary in 1970. The sanctuary was in use from the first century $\mathrm{AD}$ until the third century AD. The tablet is dated to the second century $\mathrm{AD}^{58}$ and it is a prayer for justice.

Reading of the tablet ${ }^{59}$ : Isis Muromem [i.e. Myrionyma], |tibi commendo |furtu $(m)$ meu(m). mi(hi) fac |tuto numini ma(i)es-|tati exsemplaria, | ut tu evide(s) immedi-|o qui fecit, autulit, |aut (h)eres: opertor $(i) u(m) \mid \operatorname{albu}(m)$ novu $(m), \operatorname{stragulu}(m) \mid$ nov $($ um), lodices duas me(o) ? | uso. rogo, domina, |per maiestate $(m)$ tua $(m), \mid u t(h)$ oc fortu $(m)$ repri-|ndas

Translation: Isis Myrionyma, I entrust you with what has been stolen from me. Make me proofs of your divinity and majesty, so that you publicly take away the life of the man who did this theft, indeed who stole my property: a new white coverlet, a new rug, two used blankets. I ask you, Lady, by your majesty, that you punish this theft. ${ }^{60}$

It is not usual to ask for public persecution. Urbanová mentioned just two other tablets of this demand from Germania ${ }^{61}$. As the Kempraten tablet, also this tablet is tabula ansata. ${ }^{62}$

\section{Trier}

Unfortunately, the exact place of deposition of this concrete tablet is not specified. In Trier, there are at least two sites with defixiones: an amphitheatre and a necropolis.

Reading of dfx.4.1.3/16: Tib(erium) Claudium Trev $<i=E>$ rum natione |Germanum lib(ertum) Claudii Similis rogo |te dom<i>na Isis ut illum(!) profluvio(!) | mittas et quidquid in bonis |habet in morbum megarum. ${ }^{63}$

Translation: (In the matter of) Tib. Claudius Germanus, of libertine status, a Treveran: I beseech you, Lady Isis, to cause h[im] (to suffer) a bloody flux and (turn) whatever he owns (into a deadly) illness. (To your) megaron $[\ldots]^{64}$

According to Gordon: „In this case, the principal does not communicate to the deity the reasons for his curse. His only efforts at mollification are the term domina for Isis and the usual humble expression in prayers, rogo. The opening gambit, which names the target in the accusative, thus serving as a kind of docket-label for the divine administra-

61 Urbanová (2014: p. 251).

62 Urbanová (2014: p. 497).

63 Kropp (2008: n. 4.1.3/16).

64 Gordon \& Gasparini (2014: p. 50). 
tion, occurs elsewhere in texts claiming that the target has caused the principal financial or material damage." ${ }^{65}$

\section{Seth}

"Egyptian chthonic god of wisdom and spells; the enemy of Osiris; associated with the desert and the colour red; often represented with the head of a dog or jackal." ${ }^{66}$ Seth is the god of destructive forces and desert. ${ }^{67}$ Used often in black magic with different names (Bolchoseth, Erbeth) ${ }^{68}$ Especially in Athens often he is conjoined with Typhoon and invoked among the names known from Old Testament. ${ }^{69}$ However, in Bible there is another Seth, son of Adam and Eve. So, there is a possibility that the named Seth is the Biblical one, not the Egyptian.

Two tablets from Rome (Italy) and two from Athens (Greece) invoke Seth. Although, while mentioning Seth, the great number of tablets from Porta San Sebastiano in Rome comes to mind, because they are still called Sethian tablets. On those tablets, the god is not named, and the calling is not appropriate. They are still connected to oriental gods as they are pictured on some of them, e. g. Osiris.

\section{Fountain of Anna Perenna}

The fountain was discovered and excavated during the building of an underground garage near Piazza Euclide (Rome) in $1999 .^{70}$ The fountain consisted of two parts, a cistern and a basin. The magical objects (pine cones, eggshells, curse tablets, etc.) were found in the basin near the spring. The technique used to build the basin is datable to the late antiquity. The find of pieces of wine-amphorae state the date more precisely to the end of the fourth and beginning of the fifth century AD. Between finds, there were about twenty-six curse tablets, six of them found in oil lamps. ${ }^{71}$

The first curse naming Seth is not on a flat tablet as usual, but on the lead container. The magical figurines were found in such containers. ${ }^{72}$

65 Gordon \& Gasparini (2014: p. 50).

66 Gager (1999).

67 Dunn (2015).

68 „I invoke you through your ancient names known by thy true worshipers! Sutuakh, Typhon, Bolchoseth, Erbeth, Pakerbeth, Set!“ (Luciferic bible, 58).

69 Jordan (1998: p. 205).

70 Piranomonte (2010).

71 Piranomonte (2010: pp. 191-192).

72 Blänsdorf (2010: p. 232). 


\begin{tabular}{|c|c|c|}
\hline Sete & & \\
\hline Mnu & $(\mathrm{Z})$ & TIAS \\
\hline
\end{tabular}

Reading of the second curse:.......at $\mid[S]$ eth $\mid$ et ille te $\mid$ rogat il[li] o<mnia? $\mid\langle\mathrm{u}\rangle$ xor eam [con-]|fiteatur fem[inam | [sa-]n(c)tas nimfa[s] | ro<go $>$ uo[s] | bon< ... le le ${ }^{73}$ Translation: Seth (?) and he asks you to give him everything... his wife she...he/she should confess, the woman, holy Nymph I ask you ...74

Oriental gods were invoked often on the prayers for justice, as curse tablets from Kempraten, Belo and most from Mainz. The site in Mainz is exceptional because of the number of finds. In this way also types of curses vary. Along to prayers for justice, there are judicial curses, love curses and just lists of names. Magna Mater and Isis appear mainly on Latin tablets. Seth's name (in different forms) is often used in Greek tablets. Only the cult of Magna Mater is mostly in demand of fire to deliver the tablet to the goddess. Isis' and Seth's tablets are often deposited in water. But all the types of deposition are sorely related to the sacred places as temples and sanctuaries, sacred springs, etc. Most of the tablets are dated to the second and third century AD.

Concerning texts of the curses, oriental gods are mostly demanded by the word rogo ${ }^{75}$ Kropp defines the category of this curses as Aufforderungsformel (request formula). ${ }^{76}$ Urbanová compares this type with Faraone's ${ }^{77}$ definition of Greek prayer formula: "Faraone characterizes this formula in Greek defixiones as an appeal addressed to the gods or daemons with the intention of making them carry out the requested curse or restriction (through the 2nd sg./pl. imper.). This definition is unsuitable for Latin production, however, as it only accounts for one facet of the whole spectre of such pragmatically aimed constructions. A. Kropp (2008a, $149 \mathrm{ff}$.) defines this type of curse as a formula by which its author commits his/her affairs to the supernatural powers by means of a request for divine intervention. Thus, the curse can be carried out only with some external assistance." 78 According to her, the curses with rogo can be subcategorised as "Explicitly performative formulae with the predicates expressing a plea or a request in the $1^{\text {st }} \mathrm{sg}^{\text {" }} \cdot{ }^{79}$

73 Blänsdorf (2010: p. 234).

74 English translation by the author according to Blänsdorf (2010: pp. 219-220).

75 "To ask (for)".

76 Kropp (2008: p. 214).

77 Faraone (1991: p. 5)

78 Urbanová (2014: p. 60-61).

79 Urbanová (2014: p. 61). 


\section{Conclusions}

Even if the cults of Magna Mater and Isis were officially introduced to Rome in the third and second centuries $\mathrm{BC}$, the tablets invoking these oriental goddesses and sanctuaries devoted to them are younger.

"These cases at Baelo Claudia and Trier are exceptional among 'prayers for justice' only in being addressed to Isis. It is thus relevant to point out that the thirty-four curse tablets found in the joint temenos of Isis and Mater Magna in the centre of Mogontiacum/Mainz (Germania Superior) in 1999 are addressed exclusively to Mater Magna and Attis rather than to Isis, although the great majority of conventional dedications are addressed to the latter. One possible explanation for this absence is that the relevant sacrificial pit connected with the temple of Isis was never found; this seems unlikely since that area of the site was fully excavated. The alternative is that, in competition with Mater Magna and Attis, Isis was not regarded as an appropriate divinity at Mogontiacum." 80

There are only a few texts of curses in the Graeco-Egyptian tradition found in Europe and they are dated from the second half of the second century to the late fourth century. The increasing number of the invoking to nekydaimones ${ }^{81}$ can be observed, also appeal "to purely magical deities, such as Ablanathanalba, Eulamo, Abrasax, or Lailam Semesilam, to highly local demons such as Sarbasmisarab or Baitmo Arbitto, or to powerful names derived from the Jewish tradition, such as Iaô, Sabaôth, Adonai, the God of Abraham." ${ }^{2}$ The Egyptian deities were not in the same position as those mentioned. "One implication, no doubt, is that practitioners outside Egypt, though trained in the temple tradition, whether directly or indirectly, increasingly struck out on their own, selecting the explicitly esoteric or "magical" aspects of the repertoire rather than the standard deities of the Isiac cults, which by now had been assimilated into the mainstream Graeco-Roman religious context." ${ }^{3}$

From the archaeological point of view, there is a pattern of disposition of the tablets invoking Magna Mater - the goddess. Those tablets had mainly traces of melting on them in a form of blue blurs. It seems that they weren't meant to be melted completely, but only held over the fire. As the other oriental gods on curse tablets are mainly placed to water, there should be a connection of Magna Mater and fire, particularly in the second century AD. However, not all the tablets from Mainz were found in the main precinct and fire pits. Still, the need for fire to deliver the message to the goddess could be applied as in Kempraten the fire blurs are present as well. Also, fire altars, where the ritual took place, were in the temple precinct. For some of the tablets. other offerings were not needed as the cursed person was "sacrificed" by the tablet to gods (e. g. DTM 4).

80 Gordon \& Gasparini (2014: p. 50).

81 The spirit of the dead person in the tomb.

82 Gordon \& Gasparini (2014: p. 53).

83 Gordon \& Gasparini (2014: p. 53). 


\section{Bibliography}

Ackermann, R. (2013). Der Vicus von Kempraten, Gde. Rapperswil-Jona SG (Schweiz) - Erkenntnisgewinn nach fünf Jahren Grossgrabungen (2005-2010). In A. Heising (Ed.), Neue Forschungen zu zivilen Kleinsiedlungen (vici) in den römischen Nordwest-Provinzen. Akten der Tagung Lahr 21.-23. 10.2010 (pp. 247-259). Bonn: Verlag Dr. Rudolf Habelt GmbH.

Alvar, J. (2008). Romanising Oriental Gods: Myth, Salvation, and Ethics in the Cults of Cybele, Isis, and Mithras. Leiden: Brill.

Blänsdorf, J. (2010). Religion and Magic at Rome: the Fountain of Anna Perenna. In R. L. Gordon, \& F. Marco Simón (Eds.), Magical Practice in the Latin West: Papers from the International Conference Held at the University of Zaragoza, 30 Sept.-1 Oct. 2005 (pp. 215-244). Leiden - Boston: Brill.

Blänsdorf, J. (2012). Die Defixionum Tabellae des Mainzer Isis- und Mater Magna-Heiligtums. Mainz: Generaldirektion Kulturelles Erbe.

Bonneville, J.-N., Dardaine, S., \& Le Roux, P. (1988). Belo, V: L'épigraphie: les inscriptions romaines de Baelo Claudia. Madrid: Casa de Velázquez.

Chalupa, A. (2011). Velká Matka a Attis na Proklínacích Tabulkách: Role Orientálních Božstev v Antické Magii a Náboženství. Religio: Revue pro Religionistiku, 19(2), 237-252.

Dunn, P. (2015). The Practical Art of Divine Magic: Contemporary E Ancient Techniques of Theurgy. Woodbury: Llewellyn Publications.

Eiland, M. (2004). The Holy Precinct in Mainz: Magna Mater and Isis. Minerva, 15(3), 24-25.

Gager, J. (1999). Curse Tablets and Binding Spells from the Ancient World. New York: Oxford University Press.

Gordon, R. L. (2012). "Ut tu me vindices": Mater Magna and Attis in Some New Latin Curse-Texts. In A. Mastrocinque, \& C. Giuffrè Scibona (Eds.), Demeter, Isis, Vesta and Cybele (pp. 195-212). Stuttgart: Steiner.

Gordon, R. L., \& Gasparini, V. (2014). Looking for Isis "the Magician" $\left(h k_{3} y \cdot t\right)$ in the GraecoRoman World. Bibliotheca Isiaca, 3, 39-53.

Jordan, D. R. (1998). Defixiones from a Well near the Southwest Corner of the Athenian Agora. Hesperia, 54, 198-254.

Koch, P., Lieb, H., \& Frei-Stolba, R. (2011). Eine neue Fluchtafel aus Kempraten (Kt. St. Gallen / CH). Ductus, Association internationale pour l'étude des inscriptions mineures, 15, 113-122.

Kropp, A. (2008). Defixiones. Ein aktuelles Corpus lateinischer Fluchtafeln. Speyer: KartoffeldruckVerlag.

Piranomonte, M. (2010). Religion and Magic at Rome: the Fountain of Anna Perenna. In R. L. Gordon, \& F. Marco Simón (Eds.), Magical Practice in the Latin West: Papers from the International Conference Held at the University of Zaragoza, 30 Sept.-1 Oct. 2005 (pp. 191-214). Leiden - Boston: Brill.

Roller, L. E. (1999). Search of God the Mother: the Cult of Anatolian Cybele. Berkeley: University of California.

Stadler, M. A. (2017). New Light on the Universality of Isis (pVienna D. 6297+6329+10101). In S. Nagel, J. F. Quack, \& C. Witschel (Eds.), Entangled Worlds. Religious Confluences between East and West in the Roman Empire. The Cults of Isis, Mithras and Jupiter Dolichenus. (Orientalische Religionen in der Antike, 22; pp. 232-243). Tübingen: Mohr Siebeck. 
Tomlin, R. S. O. (2010). Cursing a Thief in Iberia and Britain. In R. L. Gordon, \& F. Marco Simón (Eds.), Magical Practice in the Latin West: Papers from the International Conference Held at the University of Zaragoza, 30 Sept.-1 Oct. 2005 (pp. 245-273). Leiden - Boston: Brill.

Tortchinov, E. A. (1998). Cybele, Attis, and the Mysteries of the "Suffering Gods": A Transpersonal Interpretatio. International Journal of Transpersonal Studies, 17(2), 149-159.

Urbanová, D. (2014). Latinské proklínaci tabulky na území ř́mského impéria. Brno: Masarykova univerzita; Host.

Veale, S. (2017). Defixiones and the Temple Locus: The Power of Place in the Curse Tablets at Mainz. Magic, Ritual, and Witchcraft, 12(3), 279-313.

Witteyer, M. (2004). The sanctuary of Isis and Mater Magna. Mainz: Philipp von Zabern.

Zach, B. (2002). Vegetable Offerings on the Roman Sacrificial Site in Mainz, Germany - Short Report on the First Results. Vegetation History and Archaeobotany, 11(1/2), 101-103.

Mgr. Michaela Kellová // M.Smiejova@seznam.cz

Institute of Classical Archeology

Charles University, Faculty of Arts

Nám. Jana Palacha 2, 11638 Prague 1, Czech Republic

Toto dílo Ize užít v souladu s licenčními podmínkami Creative Commons BY-SA 4.0 International (https://creativecommons.org/licenses/by-sa/4.0/legalcode). Uvedené se nevztahuje na díla či prvky (např. obrazovou či fotografickou dokumentaci), které jsou v díle užity na základě smluvní licence nebo výjimky či omezení príslušných práv. 
